\title{
Technologies of Friendship in the Context of Conflict in Social Activism: The Confrontation between Students and Rectorship at The University of Buenos Aires
}

\author{
Syd Krochmalny \\ Faculty of Philosophy and Arts, University of Buenos Aires, Argentina
}

Copyright $(2016$ by authors, all rights reserved. Authors agree that this article remains permanently open access under the terms of the Creative Commons Attribution License 4.0 International License

\begin{abstract}
This article discusses two approaches to performance art, both of which have been declared, historically, in direct opposition with the other. On one side, the performance is a disruptive and interventionist procedure that provokes the participation of the audience spontaneously, and on the other hand it is a constructive and ameliorative collaborative directed at the spectators involving them as preplanned participants. Through a social performance that includes two different political strategies, this paper analyses the possibility of articulate, conceptual and pragmatically antagonism, using collaboration tools from the art tradition, building a methodology for Social Sciences.
\end{abstract}

Keywords Social Technologies, Performance, Methodology

\section{Introduction}

This article is a reflection of a conceptual and pragmatic performance that involves procedures from the Avant-Garde to the Contemporary Visual Arts. Historically, Performance Art and Participation Art were developed in one tradition of "creativity" collaboration, and the other of "political" antagonism (Bishop: 2004; 2005). This paper tries to disassemble this historical opposition and articulate some elements of both aesthetics through a social experiment.

The point of departure for this article is the aesthetic and political dimensions of Participation Art in which the figure of spectator engages itself like a social actor in an artwork and at the same time in a concrete political action. The action appropriates artistic form as a way to bring art closer to politics using political tools to make art. With this concept, the artwork doesn't distinguish between its autonomy and heteronomy. And at the same time, the political action blends its boundaries with the artwork.

This social performance took place in the University of Buenos Aires between 2008 and 2012. It tried to combine artistic procedures in a collaborative methodology for social sciences. From the "crisis" in social science methods (quantitative and qualitative) that has taken hold in recent years, it has been a flowering of different qualitative research methods, including participatory approaches and a focus on the sensory and emphasis on their importance in facilitating a more "embodied knowledge" of social phenomena beyond verbal narratives and cognition. This article discusses the potential use of artistic methods in Social Sciences.

\section{Situation}

At the end of 2008, activists from the Student Centre $(\mathrm{CECSO})^{1}$ decided to take over the three campuses at the Faculty of Social Sciences at the University of Buenos Aires. The move was prompted by the students' demands for structural improvements, a higher budget and the completion of the new multi-department centre. All academic activity within the university building was suspended and classes were held in the streets. The students held assemblies, public classes and demonstrations. $^{2}$

The principle issue was the necessity to provide adequate

\footnotetext{
${ }^{1}$ Presided by OKTUBRE, a leftist front formed in 2003 by the Partido Obrero, the MST, "El Viejo Topo", the Partido de los Trabajadores Socialistas (PTS) and the "29 de Mayo". In 2004 it was joined by Praxis (formerly known as Socialismo Revolucionario that separated from the PTS for considering it "sectarian" and "workerist") and the MAS. During 2005 the MST was fractured with the documents 1 and 2 briefly coexisting and in 2007 it was joined by the COR (another breach of the PTS). Most members of the front are of "trotskist" ideology.

During the same period, the University Assembly voted to reform the university status with 164 affirmative votes, 16 negative and 8 abstentions. During the session, groups of student activists tried to break the police barrier and enter the place with the goal of requiring their participation in university government. Christian Henkel, co-president of the FUBA, said the assembly intended to deepen neoliberal policies at the university. He urged them to remove the fences and withdraw the police guard in order to involve all the student representatives. The university assembly did not accept the demands, and the reform was approved. Meanwhile, there were some differences between some student sectors and the leftist conduction. Oktubre, the front that then had the presidency, was again fractured. In November elections were won by a front of "Independent Left" called "El Tren". This coalition is composed by the groups "Contrahegemonía" (Corriente Universitaria Julio Antonio Mella), "La Mala Educación" and "Agrupación Universitaria Prisma".
} 
space for student and faculty members to socialize. The students held a meeting and decided to extend the student centre's dining area into the car park, on university property. The student activists took the opportunity to reappropriate the car park as a space for socializing. During the demonstration, the activists occupied no more than 5 percent of the total area of the car park.

During the summer of 2009, an independent student group and members of the Student Centre began the construction of the dining area in the car park. The installation consisted of a roof and stone-enclosed "gardens", creating space-maximizing architecture that allowed the activists to achieve their goals. The creation of the new socializing space quickly surpassed its initial purpose of an integrated dining area, as it came to host academic, political, cultural and artistic activities.

This political act was supported by the majority of students, professors, three chairs, the Department of Sociology, artists and the founders of the Madres de Plaza de Mayo. The participation of students, student Directors and activists made this space culturally vibrant and full of life. This new cultural ecology was developed while waiting for the completion of the new Social Science building, which had been delayed. ${ }^{3}$

Nevertheless, the Rector interpreted the activists' actions as an "usurpation". This interpretation not only privileged the function of a car park above the social function of the academic space but also led to the Superior Board requesting that lawyers intervene in order to arrive at a solution. ${ }^{4}$ The faculty authorities then seemed to change tack, and admitted that the conflict between the different actors should be worked out through dialogue and without legal intervention. ${ }^{5}$

In 2009, the Student Centre received a letter that notified it of the existence of an open legal case involving the activists, and specifically naming Germán Feldman, former President of the Student Centre. The University Rector ordered the dwellers and Student Centre members to be identified, and also ordered an eviction during the summer of 2009, which was prevented by the students. The Rector's resort to the legal system was not only a setback to the activists, but also to the history of the University and its tradition of Democracy. ${ }^{6}$

\footnotetext{
${ }^{3}$ Meanwhile the university does not comply with Article 70 of its statute that attempts to "promote cultural and sports activities and the appropriate infrastructure and teaching equipment upgraded for better performance of eqducational work."

This action contradicts the stated in the university statute: all members of the university community are entitled to use and enjoy the property of the University (Article 79).

5 It also represents a serious institutional injury and a setback in the history of the institution, because the attempt to address an academic problem using the judicial power undermines the university autonomy.

The student movement in Argentina has a long tradition. Due to the conquest of the university autonomy it was established as a political model for the organization of contemporary universities. This independent cultural movement spread throughout Latin America, Spain and the United States. The University Reform is the name given to the movement promoted by students since the university strike in June 1918 at the National University of Cordoba, demanding deep reforms of structures, contents and goals of the university. It attacked the feudal, bureaucratic and undemocratic structure and its dependence on the political system. In this context, the Federación
}

\section{Technologies of Friendship and Technologies of Confrontation}

When people are grouped into communities of action and organizations constitute an inside and an outside, the borders are socially institutionalized. To live, actors must cross those borders, contacts, contrasts, conflicts and compromise to established relationships between inside and outside. These boundaries become dangerous when the contacts are blocked and can not be made, and only commitments and conflicts that can lead to violence ensue (Koselleck: 2012).

When conflict does not find a resolution protocol, and confrontation strategies are activated, the other is designed as an enemy. They are opposed semantic structures that produce the concept of enemy. These concepts and their meanings are opened and limit the perception and judgment. The concepts of enemy that is based on conflict and strategies are reflective opposition or thoughtlessly articulated in a semantic field (Koselleck: 2012).

The case being analyzed is a situation of social conflict that was developed by institutional contradictions. Tensions registered in the conflict between students and the rectory, involving the penal system was denting the traditional channels of political resolution. This project attempted to introduce some friendship strategies articulated with confrontation strategies carried out by the students (Koselleck: 2012).

The project intervened in the conflict calling on a group of artists to operate and generate artistic and social productions in the car park/ dining room space. The first premise was don't use the typical rhetoric, tactics and strategies that were used by student groups and which were similar to the artistic practices of the activist art groups: the "technologies of confrontation", which meant actions and discourses during conflict situations that consisted of opposition, protest and denunciation techniques. ${ }^{7}$

The "Opposition Strategy" is founded on the political relationship between friend and enemy, where the enemy could be the bourgeoisie, the bureaucrat or the perpetrator of genocide. This strategy is an act of resistance and vindication

Universitaria de Córdoba published the Manifesto Liminar, written by student leader Deodoro Roca, that later became the basic document of the University Reform. The movement was a critique of the relationship between knowledge and authority, showing the involvement of students in university life and decision-making with independence of outside powers (justice and church).

Activist art operates over experiments carried out in collaboration between artists and activist groups to "creatively intertwine aesthetic and communicational resources with political practices. These groups are formed by architects, journalists, and artists who seek to activate transformative practices beyond their scope of registration. These projects and strategies fuse art and activism in a peculiar way. They are collective artistic actions - of a performative type, street signs, iconographic productions, interventions in real and virtual space - that propose an immediate political impact through media coverage and the participation of social activists, human rights and ecological organizations. The repertoire of these practices is composed by performances, actions, images, urban signals and interventions. The deployment of these practices occurs in different contexts: marches, protests, tributes in central points of the city; in neighborhoods, factories, advertising posters, buildings and squares. These practices provided a visuality to the actions of protest and strategic communication. 
when facing an attack on a friend. The 'other' in the strategy of opposition is the aggressor whose function is to make those who are victimized/attacked bond together, making the conflict a reason for community, collectives and the gathering together of groups. This type of organization is formed in a defensive way. The generation and proliferation of this strategy is in line with the extent of confrontation, which thereby defines the groups' limits: it is not the "being along with" or the "we", but the conflict, "the other", which becomes the foundation for the (art) groups and for political militancy.

From this paradigm, which turned out to be inescapable since it was a main part of the situation in which the project was going to operate, it took the following elements:

a. Intervention in a conflict space between actors (mainly students and the rectorship)

b. The collaboration between artists and activist groups (members of the political groups of the student centre)

c. Media coverage (articles in different media and video documentary)

But, at the same time, it was necessary to avoid some constant elements that were part of these technologies, namely: the reproduction of the conflict centered on a friend/enemy relationship, the rhetoric of denunciation and protest, the strategy of opposition, the modality of defensive action and the verbal and material attack. The idea was to prioritize certain elements that are part of the background of the activist art tradition.

The cafeteria/car park was a situation in which the project could work artistically with other technologies, namely those that Fernanda Laguna and Cecilia Pavón had coined, towards the end of the nineties, as "technologies of friendship". ${ }^{8}$ The technologies of friendship consist of connecting and articulating fragments of the world and artists' initiatives within a vast cultural ecology in which artists proclaim themselves as their self-producers: as their own directors, curators, critics, gallerists, writers and researchers.

From these technologies we took the following guidelines:

a. The participation of artists and non-artists

b. The emphasis on the connection - philia - between different actors in conflict (activists from other parties that were not a part of the student centre, members of the board of the faculty and the deanship)

c. To build a new status quo to face the deterioration of institutions

d. To give a visible image to what was invisible before

e. A positive logic of action, by accepting heterogeneous proposals

f. To build bridges, cross-symbolic borders and multiply the opportunities for fertile encounters

g. To put the "economy of giving" into practice. In order to

8 The Technologies of Friendship are the psychic and physical skills and abilities of people articulated in groups and networks with great intensity for symbolic production. Jacoby R. Tecnologías de la amistad. In: Longoni A, ed. by. El deseo nace del derrumbe. 1st ed. Madrid: Adriana Hidalgo y Museo Centro de Arte Reina Sofía; 2011. p. 373-461 put this plan into practice, we summoned together artists who could provide practical and theoretical tools and who had previously been part of the "activist art" and "autogestive art" scenes.

\section{Tactics and Open Command Experiment}

With the technologies of confrontation as a factual situation different artists were invited to display friendly technologies. The dining room was defined as a "lumpen bar" and conceived of it as an installation in which the artists and intellectuals could intervene, configure, redesign and collaborate. $^{9}$ The artists were invited to think on-site. The common opinion was that the space lacked "visuality". If the occupation had legitimacy because of the lack of a territory for socializing, this could be crumbled with just one image. Therefore, the artists considered the need to create a "face". Another common thought was that they should work with the needs and materials on the site and accept donated materials that could be attached to those they found there.

The first activity was a visit to inspect the site, where they presented some ideas and took some photographs of the site. The second meeting consisted of reading two books, the one about the thousand seats and another on contemporary architecture; as they read they worked with four wooden spools of wire that were lying on the parking lot, sanding, painting and refinished them, and placing spinning wheels of polypropylene on them. The third meeting was within the context of the second Independent Book Fair held in the parking lot of the faculty; they continued the work on the construction of mobile tables and in the afternoon Pio Torroja, Gustavo Dieguez and Lucas Rubinich put together a discussion panel to reflect on the urban possibilities of the conflict. Other actions on site included the making of soup using ingredients from the on-site garden, contrasting with the unhealthy high-fat food served in the student cafeteria, a public general sociology class taught by Lucas Rubinich and a "Social Sculpture".

Finally, the parking lot was perceived as a privileged urban space (outside of the market), with great dimensions, scarce in that zone of Buenos Aires. The space had not been privately developed because it belonged to the university. The project evaluated the loss of potential that resulted from its use as a car park. Therefore, the architects proposed to inject political imagination so the car park became a public plaza of arts and sciences, coordinated by the university. At the same time, two underground car parks could be built. The construction and financing of this self-sustaining project would take five years. The implementation of a plan of this magnitude would bring prestige to the college, involve the

\footnotetext{
9 The dining room is an installation because it is partially built (planters and roof) and because it lacks a central perspective (multiple configurations). It includes any viewer as a participant, as an integral part of the space, and
} assumes a decentered subject and an embodied viewer. 
participation of different social actors and be an exemplary example for other community outreach projects.

\section{Conclusions}

This project ties in with emphasis on notions of performance in social science to build new methodology for the complexity of social relationships. At the same time, many social scientists have turned to different types of "performance" to conduct research through artistic practices. They are very useful in finding new modes of research, which contribute to a performance-based Social Science. Such approaches disrupt linear conceptions of research as collection, interpretation and dissemination while often engaging in a dialogical relationship with the research audience. This project could be associated with narrative-based auto ethnographies and a form of "critical pedagogy" or "emancipatory discourse". Art practices as transformative research, employing artists imaginations and intellects not only useful in constructing new knowledge, but knowledge that has the capacity to transform understanding and to explore and contest ideas and concepts. The opportunities offered by this project were to understand that community spaces could be used in creating new spaces for creative and critical inquiry.

The project articulated the technologies of friendship with the technologies of confrontation. As a factual situation, the project displayed friendly technologies. The elements of both technologies used in this project have dismounted the long-term tradition that separated analytically in discourses, the collaboration and the disruptive and interventionist performances. In other words, a tradition that seeks to provoke others and a lineage that aims to embrace a collective creativity. It was important not to neglect certain techniques of opposition because they serve to keep the pressure on and to maintain certain positions. Then it seems to be that this is a time in which to create technologies of friendship. Finally, the efforts between artists, intellectuals and students to build bridges have been beneficial to the academic community. The display of technologies of friendship articulated with the technologies of confrontation contributed to resolving the initial conflict between the student centre and the rectorship. The authorities of the University offered a new building with more infrastructure and public space to locate the Faculty of Social Sciences. It is open and working today and hosts academic, cultural and artistic activities of students and professors and is open to the community, as well.

\section{REFERENCES}

[1] Bishop C. Participation. London: Whitechapel; 2006.

[2] Bishop C. Antagonism and Relational Aesthetics. October. 2004;110:51-79.

[3] Denzin N. The Reflexive Interview and a Performative Social Science. Qualitative Research. 2001;1(1):23-46.

[4] Denzin N. Performance Ethnography. Thousand Oaks, Calif.: SAGE; 2003.

[5] Derrida, J. Políticas de la Amistad. Madrid: Trotta; 2012.

[6] Laguna F. Pavón C. Belleza y Felicidad. Buenos Aires: Fundación Proa; 2005.

[7] Jacoby R. Tecnologías de la amistad. In: Longoni A. El deseo nace del derrumbe. 1st ed. Madrid: Adriana Hidalgo y Museo Centro de Arte Reina Sofia; 2011. p. 373-461.

[8] Koselleck, R. Conceptos de enemigo. In Koselleck, R. Historias de conceptos. Estudios sobre semántica y pragmática del lenguaje político y social.. 2nd ed. Madrid: Trotta; 2012. p. 189-198.

[9] Krochmalny S. Cómo hacer y comer juntos: descripción de las distintas modalidades de producción colectiva artística y sus formas sociales. Ramona 2007;69:84-86.

[10] Krochmalny S. The Politics of Friendship and Confrontation. New York: Museum of Reclaimed Urban Space; 2014.

[11] Roberts, B. Performative Social Science: A Consideration of Skills, Purpose and Context'. Forum: Qualitative Social Research/ Sozialforschung; 9(2), Art, 58.

[12] Savage M. Burrows R. The Coming Crisis of Empirical Sociology. Sociology. 2007; 41(5):885-899.

[13] Savage M. Burrows R. Some Further Reflections on the Coming Crisis of Empirical Sociology. Sociology. 2009; 43(4):762-772.

[14] Schmitt, C. El concepto de lo político. Madrid: Alianza Editorial; 2009. 